\title{
WORKING CAPITAL MANAGEMENT AND ITS INFLUENCE ON PROFITABILITY AND SUSTAINABLE GROWTH
}

\author{
Pambayun Kinasih Yekti NASTITI ${ }^{1}$, Apriani Dorkas Rambu ATAHAU ${ }^{2}$, \\ Supramono SUPRAMONO ${ }^{3}$
}

\author{
Faculty of Economics and Business, Universitas Kristen Satya Wacana, Salatiga, Indonesia \\ E-mails: ${ }^{1}$ pampambayun@gmail.com; ${ }^{2}$ apriani@staff.uksw.edu; \\ ${ }^{3}$ supramono@staff.uksw.edu (corresponding author)
}

Received 31 October 2018; accepted 10 January 2019

\begin{abstract}
This study aims to test the effect of working capital management on firms' profitability and the effect of this relationship on sustainable growth. Our sample firms are 136 manufacturing firms listed in the Indonesian Stock Exchange from 2010 to 2017. We use data panel regression with fixed effect estimation model to analyze our data. The results demonstrate that working capital significantly affects firms' profitability. However, working capital management does not exhibit a significant direct influence on sustainable growth but a significant indirect influence through firms' profitability. Thus, this study suggests that firms need to manage their working capital to increase their profits and eventually to achieve sustainable growth. This study contributes by including sustainable growth in the analysis of the relationship between working capital and firm performance. In addition, this study will likely contribute to managers in efforts to increase sustainable growth for their enterprises through working capital management.
\end{abstract}

Keywords: working capital management, profitability, sustainable growth, cash conversion cycle, return on assets, manufacturing industry.

JEL Classification: G31, G39, C23.

\section{Introduction}

Working capital management aims to increase profitability and at the same time to enable firms to repay their mature liability by ensuring their liquidity (Pass and Pike 1996). Thus, it is necessary that firms balance these two objectives in their activities (Gitman 2011). Working capital management is closely related to the decisions on firms' asset composition and current liabilities that imply on firms' profitability (Adekola et al. 2017, Deloof 2003, Mannori and Mohammad 2012). Further, Misbah et al. (2015) indicates that working capital management is the essential element of firms' daily operating activities.

Managerial inability to manage working capital will potentially create financial difficulties for firms (Smith 1973). On the contrary, firms with well-managed working capital are likely to demonstrate increased performance (Raheman and Nasr 2007). Previous studies have shown the effects of working capital management on liquidity (Adekola et al. 2017, Attom 2016) and profitability (Al-abass 2018, Deloof 2003, Hien Tran et al. 2017, Panda and Nanda 2018, Raheman et al. 2010, Raheman and Nasr 2007). The studies not only focus on larger firms as their sample firms (Altaf and Shah 2018, Atta et al. 2017, Bagh et al. 2016) but also on small and medium enterprises (Afrifa 2015, Afrifa and Tingbani 2018, Lamptey et al. 2017).

Firms' ability to manage their working capital will not only increase their profits but also their growth. In relation to firms' growth, Higgins (1977) introduces the concept of sustainable growth rate that indicates firms' maximum sales growth without having to change their financing decisions. Sustainable growth rate refers to firms' maximum growth rate by only relying on internal financing, and not on

Copyright $\odot 2019$ The Authors. Published by VGTU Press.

This is an Open Access article distributed under the terms of the Creative Commons Attribution License (http://creativecommons.org/licenses/by/4.0/), which permits unrestricted use, distribution, and reproduction in any medium, provided the original author and source are credited.. 
additional financing (such as new investors or long-term liabilities). Ashta (2008) and Fonseka et al. (2012) suggest that firms base their operating activities on sustainable growth. Firms that operate above their sustainable growth are potentially prone to financial distress or even bankruptcy because of excessive financial leverage. Meanwhile, firms that fail to achieve sustainable growth run a risk of slow or even stagnant growth.

The ability to manage working capital is closely related to sustainable growth (Churchill and Mullins 2001, Rădăşanu 2015). For example, firms that manage their sales policies well will produce sufficient cash flows for their operating activities and eventually increase their profits. Further, profitability plays an important role in sustainable growth (Shapiro and Balbirer 2000). Several studies, such as Amouzesh et al. (2011), Mukherjee and Sen (2018) and Manaf et al. (2018) support this argument by demonstrating the effect of profitability on firms' sustainable growth. It then can be predicted that working capital management affects sustainable growth through firms' profitability. Thus, the role of firms' profitability as a mediating variable between working capital management and sustainable growth is an interesting research avenue.

Specifically, this study aims to: (i) test the effect of working capital management on firms' profitability, (ii) investigate the effect of firms' profitability on sustainable growth, and (iii) analyze the effect of working capital management on sustainable growth as mediated by profitability. We focus on manufacturing firms because these firms exhibit a relatively high proportion of working capital and even it is not uncommon that working capital constitutes more than a half of manufacturing firms' total assets (Ahmad and Samim 2018, Deloof 2003, Wasiuzzaman 2015). Besides, manufacturing firms play a strategic role in countries' national economy (Raheman et al. 2010). Specifically, manufacturing firms exhibit the largest contribution to GDP (20.16\%) and export (75.99\%) of the Indonesian economy. Indonesia even ranks fourth from 15 countries in terms of the contribution of the manufacturing sector to GDP. As a developing country, Indonesia itself exerts a significant influence on the economic growth in South East Asia because it recorded the economic growth of 5\% in 2017 (according to Statistics Indonesia) and have the largest GDP in this region.

This study contributes to the literature by extending the working capital research model that heavily focuses on profitability. Most of the previous studies focus on only the impact of working capital on profitability (Deloof 2003, Hien Tran et al. 2017, Raheman et al. 2010) although profitability itself affects sustainable growth (Amouzesh et al. 2011, Hien Tran et al. 2017, Manaf et al. 2018, Shapiro and Balbirer 2000). Further, working capital management is also closely related to sustainable growth (Churchill and Mullins 2001, Rădăşanu 2015). However, so far there are no studies that investigate the effect of working capital management on sustainable growth. It is also expected that this study offers a managerial implication by suggesting that managers prepare more specific working capital management to enhance their profitability and to achieve sustainable growth.

\section{Literature review and hypothesis development}

The importance of working capital management is closely related to the fact that most companies invest large amounts of money into current assets and rely on current liabilities as a source of financing (Deloof 2003, KoralunBereźnicka 2014) Working capital management consists of all decisions that are related to the management of current assets and liabilities, i.e. determining the optimal amount of cash, receivables, inventory, and current liabilities and the relationship between current assets and current liabilities (Abuzayed 2012). Working capital management also refers to financing and investing activities and net current asset control through various firms' policies (Padachi et al. 2012). By managing their working capital, firms can shorten their operating and cash cycles and eventually increase their profitability (Hien Tran et al. 2017, Raheman et al. 2010). The shorter the firms' operating and cash cycles, the more likely are firms to generate profits.

In recent years, scholars have begun to demonstrate their interests in investigating the strategic role of working capital management in firms. Most previous studies indicate that working capital management affects profitability. Raheman et al. (2010) analyze the relationship between working capital management and profitability in 204 listed manufacturing firms in the Karachi Stock Exchange, Pakistan, from 1998 to 2007. The findings suggest the negative relationship between working capital management as indicated by inventory and receivable turnover with firms profitability (as indicated by net operating profit). Using 88 US firms listed in the New York Stock Exchange in 20052007 as the sample firms, Gill et al. (2010) show that shortening the receivable collection period arguably increases profitability. Vural (2012) have also investigated the role of working capital management in explaining profitability. Using 75 manufacturing firms listed in the Istanbul Stock Exchange in 2002-2009 as the sample, they demonstrate that the receivable collection period and cash cycle are negatively related to firms' profitability. Thus, the results imply that longer receivable collection period will negatively affect firms' profitability. In a similar vein, the longer cash cycle reduces firms' profitability. Further, using 200 Vietnamese manufacturing firms listed in the Hanoi Stock Exchange (HSE) from 2010 to 2012, Hien Tran et al. (2017) show that working capital management significantly affects profitability. Based on the previous arguments and empirical studies, the following is our first hypothesis: 
H1: Working capital management significantly affects firms' profitability.

Sustainable growth indicates annual sales growth that is consistent with firms' financing policy (Higgins 1977). Based on firms' financing policy, managers will be able to determine the maximum sales level of their firms (Momčilović et al. 2015) that will not negatively affect their cash flows (Ashta 2008). Firms' financing policy is related to their decisions not to issue new shares and maintain their debt to equity (DER) ratio at certain levels. Consequently, the focus of sustainable growth is not only the funds needed to achieve expected growth rate but also the extent of firms' ability to develop by using their existing internal financing sources (Shapiro and Balbirer 2000).

Rădăşanu (2015) explains that working capital management is closely related to sustainable growth. An effective working capital management helps firms maintain their liquidity that enables them to have sufficient cash flows to repay mature short-term liabilities and to acquire lower cost of capital (Barine 2012). Further, previous studies of Amouzesh et al. (2011) and Fonseka et al. (2012) find that liquidity affects sustainable growth. Besides, effective working capital helps firms reduce the stock-out risk and acquire sufficient financing sources to operate. Thus, firms will manage to achieve sustainable growth. Based on these arguments, we propose our second hypothesis:

H2: Working capital management significantly affects sustainable growth.

Sustainable growth is in line with the pecking order theory that argues that firms should prioritize internal financing sources over the external ones such as debt and share issuance because internal financing sources have a lower cost of capital. Issuing new shares potentially provide a negative signal because firms issue new shares usually when they lack sufficient internal funds and firms cannot issue new debts (Palombini and Nakamura 2012).

The availability of internal financing is closely related to firms' ability to generate profits. Thus, firms have to constantly strive for increasing their profitability. Amouzesh et al. (2011) find the relationship between profitability and sustainable growth. Further, Manaf et al. (2018) also demonstrate a significant positive relationship between profitability and sustainable growth. All in all, these studies suggest that higher profitability will increase sustainable growth. It is possible that working capital management affects sustainable growth through profitability. As stated by Churchill and Mullins (2001) if firms manage to shorten their operating cycles, to reduce cash needed during their operating cycles, and to generate more cash during their operating cycles, they can increase their profits and eventually their sustainable growth. Consistent with the previous arguments and empirical studies, the following is our third hypothesis.
H3: Firms' profitability mediates the significant effect of working capital management on sustainable growth.

\section{Research method}

\subsection{Data sample}

Our sample firms are all manufacturing firms listed in the Indonesian Stock Exchange (IDX) from 2010 to 2017 (136 firms). We use the 2010-2017 period as our observation years because in these years firms have arguably survived the latest global financial crisis in 2008. Thus, their financial condition is less likely to be affected by the crisis. We generate our data from sample firms' relevant published financial statements. Our panel data approach compares the financial condition of firms from the same industry in a single country (Indonesia). Specifically, our data sources are firms' formal websites, the website of the Indonesian Stock Exchange (http://www.idx.co.id) and IDN Financials (https://www. idnfinancials.com).

\subsection{Variables measurement}

The dependent variable is sustainable growth. We measure this variable by using the sustainable growth rate (SGR) that is the multiplication between ROE and Retention Rate (Higgins 1977). Meanwhile, our independent variable is working capital management as empirically indicated by cash cycle (CCC) because theoretically cash cycle shows the period needed by firms to convert their cash outflows to cash inflows. This indicator strongly represents firms' working capital management (Hien Tran et al. 2017). Further, profitability, as measured with return on assets or ROA (Mehta 2017, Oseifuah and Gyekye 2016) is the mediating variable. Lastly, our control variables are the firm size (FRSIZE), sales growth (SALESGR), leverage (LEV) and total asset turnover (TATO). We use these control variables to mitigate the size effect. Several previous studies on working capital management use leverage as the control variable because this variable is likely to be closely related to the change in working capital management (Deloof 2003, Hien Tran et al. 2017, Vural 2012).

\subsection{Analytical technique}

We empirically test the relationship between variables and to analyze the presence of the mediating variable in this relationship using STATA version 14. In line with the formulation of the hypothesis, we use the following estimation model:

$$
\begin{aligned}
& R O A_{i t}=\beta_{0}+\beta_{1} C C C_{i t}+\beta_{2} \text { SALESGR }_{i t}+ \\
& \beta_{3} \text { FRSIZE }_{i t}+\beta_{4} L E V_{i t}+\beta_{1} \text { TATO }_{i t}+\varepsilon_{i t} \\
& S R_{i t}=\beta_{0}+\beta_{1} C C C_{i t}+\beta_{2} \text { SALESGR }_{i t}+ \\
& \beta_{3} \text { FRSIZE }_{i t}+\beta_{4} L E V_{i t}+\beta_{1} \text { TATO }_{i t}+\varepsilon_{i t}
\end{aligned}
$$




$$
\begin{aligned}
& S G R_{i t}=\beta_{0}+\beta_{1} C C C_{i t}+\beta_{2} \text { ROA }_{i t}+\beta_{3} S A L E S G R_{i t}+ \\
& \beta_{4} \text { FRSIZE }_{i t}+\beta_{5} L E V_{i t}+\beta_{6} \text { TATO }_{i t}+\varepsilon_{i t} .
\end{aligned}
$$

Note:

SGR - Sustainable Growth Rate, dependent variable

$C C C$ - Cash Conversion Cycle, independent variable

$R O A$ - Return on Assets, mediating variable

SALESGR - Sales Growth, control variable

FRSIZE - Firm Size, control variable

$L E V$ - Leverage, control variable

TATO - Total Assets Turnover, control variable

$\beta_{0}-$ Constant

$\beta_{1-6}-$ Regression Coefficient

Model I demonstrates the direct effect of the CCC variable as an indicator of the working capital management variable on $R O A$ as an indicator of profitability. Meanwhile, model II explains the direct effect of the CCC variable on the $S G R$ variable. Lastly, model III shows the impact of the CCC variable on the $S G R$ variable through $R O A$ as a mediating variable. The conceptual relationship among dependent, mediating and independent variables used in this study is presented in Figure 1.

According to Baron and Kenny (1986), there are three alternative results of the mediating effect. Firstly, the effect of the independent variable on the dependent variable becomes insignificant (or vice versa) in the presence of the mediating variable. This effect implies that the mediating variable acts as the full mediator in the relationship. Secondly, the effect of the independent variable on the dependent variable remains significant in the presence of the mediating variable, suggesting that partial mediation exists. Thirdly, when these two conditions are absent, the mediation effect is considered insignificant.

Baron and Kenny (1986) explain that there are two conditions that have to be fulfilled for the method to qualify, namely the $a, b$, and c coefficients should be significant and the c' coefficient $<c$. However, the significance of the $a$ and $b$ coefficients is sufficient to indicate the mediating effect although the c coefficient is insignificant (MacKinnon 2008), implying that it is likely that the relationship between the independent variable and the dependent variable must be through the mediating variable. Besides, there is an

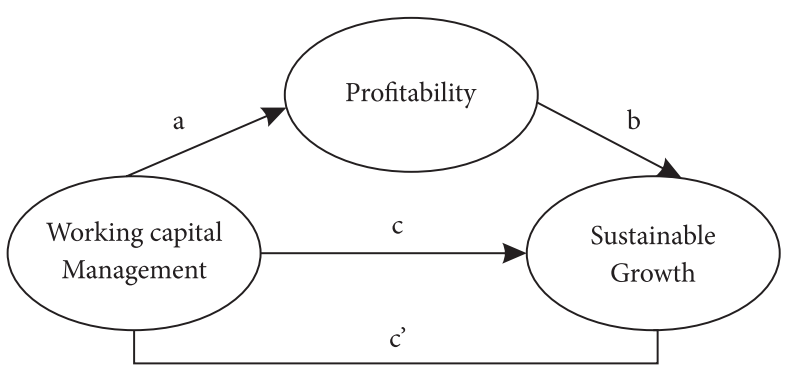

Figure 1. Mediating effect alternative method to statistically ensure the significance of the mediating effect, namely by multiplying the $\mathrm{a}$ and $\mathrm{b}$ coefficients and then dividing the results with the standard errors of both coefficients $\left(S_{a b}=\sqrt{b^{2} S_{a}^{2}+a^{2} S_{b}^{2}+S_{a}^{2} S_{b}^{2}}\right)$. This method, labeled as the product of the coefficient method, searches for $Z$ value. If $Z$ value is grthe eater than the value of $Z_{\text {table }}$, then there is an indirect effect of the independent variable on the dependent variable or, in other words, the mediating effect exists. Sobel test, Arorian test, and Goodman test use this approach to test the significance of the mediating effect.

Before testing our hypothesis, we initially determine the appropriate panel data estimation model using the following tests: Chow test, Hausman test, and Lagrange Multiplier. Chow test aims to determine whether a common effect or fixed effect model is more appropriate to estimate panel data (H0: common effect model, H1: fixed effect model). Meanwhile, the Hausman test selects a fixed effect or random effect model (Ho: random effect model, H1: fixed effect model). Further, the Lagrange multiplier test selects random or common effect (Ho: common effect model, $\mathrm{H} 1$ : random effect model). If $\mathrm{p}$-value of each test $<0.05$ then $\mathrm{Ho}$ is rejected and vice versa. We run a Lagrange multiplier test after Chow test or Hausman test.

\section{Findings and result}

\subsection{Descriptive statistics}

The descriptive statistics describe our data by using the mean, standard deviation, minimum, and maximum values as the indicators. This study uses data from 136 Indonesian manufacturing firms from 2010 to 2017 . We generate the data for our independent, mediating, dependent, and control variables from the Indonesian Stock Exchange and IDN Financials websites.

Table 1 shows that the mean value of the sustainable growth rate of Indonesian manufacturing firms is 3.45\%. Although Indonesian manufacturing firms grow, they still lack internal funds to facilitate their growth. Long-term

Table 1. Descriptive Statistics (secondary data, processed)

\begin{tabular}{|c|c|c|c|c|}
\hline Variables & Mean & $\begin{array}{c}\text { Standard } \\
\text { Deviasi }\end{array}$ & Minimum & Maximum \\
\hline SGR (\%) & 3.45 & 30.23 & -483.04 & 192.29 \\
\hline CCC (days) & 131.57 & 109.57 & -548.53 & 729.54 \\
\hline ROA (\%) & 5.24 & 10.77 & -81.11 & 74.07 \\
\hline $\begin{array}{c}\text { SALESGR } \\
(\%)\end{array}$ & 11.55 & 37.28 & -100 & 594.73 \\
\hline FRSIZE & 21.26 & 1.57 & 17.13 & 26.40 \\
\hline LEV (\%) & 33.72 & 45.35 & 0.04 & 478.05 \\
\hline $\begin{array}{c}\text { TATO } \\
\text { (times) }\end{array}$ & 1.08 & 0.57 & 0.02 & 4.14 \\
\hline
\end{tabular}


liabilities remain important financing sources for these firms. Meanwhile, the mean value of firms' profitability is only $5.24 \%$ and relatively varies between firms as indicated by the standard deviation and the range between the minimum and maximum values. On the other hand, in general, Indonesian manufacturing firms exhibit cash cycles. Specifically, firms in machinery and heavy equipment sub-sectors exhibit cash cycles. Besides, firms in cigarette and textile and garment subsectors have greater inventory, causing their inventory periods to be also high. We conjecture that firms with greater inventory levels aim to ensure the availability of their materials.

\subsection{Hypothesis testing and discussion}

This study uses the Pearson correlation matrix of the total sample and VIF (Variance Inflation Factor) to test the multicollinearity between explaining variables. Table 2 displays the results of the Pearson correlation and VIF. The results suggest that no correlation coefficient is higher than 0.7 and relatively low while no VIF value is greater than 10 . Thus, it can be concluded that there is no multicollinearity problem.

We run panel data regression to test our hypotheses. This method offers an advantage that is absent in the time-series and cross-section methods. In this respect, the panel data method manages to overcome several problems such as heteroscedasticity and multicollinearity (Baltagi 2005). Initially, we run several tests to determine the appropriate panel date estimation method. Specifically, the Chow test determines whether the pooled regression or fixed effect is more appropriate to determine the panel data estimation method. As shown by Table 3, the results of the Chow test indicates that the fixed effect is more appropriate to estimate all regression models (prob $>F$ is less than 0.05). We then run Hausman test to select a fixed effect or random effect. The results of the Hausman test suggest that fixed effect is more appropriate for all models. To ensure the robustness of our results, we apply the robustness fixed effect test (Table 3).

The table demonstrates that working capital management exhibits a significantly positive influence on firms' profitability (Model 1). In other words, longer cash conversion cycles even increase firms' profitability. We explain these findings by suggesting that longer cash cycles due to higher levels of inventories will reduce costs driven by stockouts. Thus, firms are willing to stock more inventories to ensure the continuity of their business processes. Besides, longer cash cycles are likely to be affected by firms' decisions

Table 2. Correlation Matrix (secondary data, processed)

\begin{tabular}{|c|c|c|c|c|c|c|c|c|}
\hline & $S G R$ & CCC & ROA & SALESGR & FRSIZE & LEV & TATO & VIF \\
\hline SGR & 1 & & & & & & & \\
\hline CCC & -0.097 & 1 & & & & & & \\
\hline ROA & 0.400 & -0.117 & 1 & & & & 1.55 \\
\hline SALESGR & 0.103 & 0.001 & 0.095 & 1 & & & 1.17 \\
\hline FRSIZE & 0.044 & -0.206 & 0.148 & 0.021 & 1 & & 7.99 \\
\hline LEV & -0.110 & 0.095 & -0.320 & -0.017 & -0.020 & 1 & 1.75 \\
\hline TATO & 0.177 & -0.372 & 0.318 & 0.050 & -0.165 & -0.030 & 1 & 5.33 \\
\hline
\end{tabular}

Table 3. Regression Results (secondary data, processed)

\begin{tabular}{|c|c|c|c|c|c|c|}
\hline Variables & \multicolumn{2}{|c|}{ Model $1(C C C-R O A)$} & \multicolumn{2}{|c|}{ Model 2 (CCC-SGR) } & \multicolumn{2}{|c|}{ Model 3 (CCC-ROA-SGR) } \\
\hline$S G R$ & Fixed Effect & $\begin{array}{c}\text { Fixed Effect } \\
\text { Robust }\end{array}$ & Fixed Effect & $\begin{array}{c}\text { Fixed Effect } \\
\text { Robust }\end{array}$ & Fixed Effect & $\begin{array}{c}\text { Fixed Effect } \\
\text { Robust }\end{array}$ \\
\hline CCC & $0.02^{* * *}$ & $0.02^{\star * *}$ & $-0.06^{\star * *}$ & -0.06 & $-0.08^{\star * *}$ & $-0.08^{*}$ \\
\hline$R O A$ & & & & & $1.70^{* * *}$ & $1.70^{*}$ \\
\hline SALESGR & $0.04^{* * *}$ & $0.04^{* * *}$ & $0.12^{\star * *}$ & 0.12 & $0.07^{\star}$ & 0.07 \\
\hline FRSIZE & -0.46 & -0.46 & 2.73 & 2.73 & 3.38 & 3.38 \\
\hline$L E V$ & $-0.11^{\star * *}$ & $-0.11^{\star * *}$ & -0.05 & -0.05 & $0.14^{\star *}$ & $0.14^{* *}$ \\
\hline TATO & $6.46^{* * *}$ & $6.46^{\star * *}$ & $12.57^{\star \star}$ & $12.57^{*}$ & 2.44 & 2.44 \\
\hline F-test & $35.19^{* * *}$ & $17.71^{\star * *}$ & $6.81^{\star * *}$ & $3.12^{\star *}$ & $22.92^{\star * *}$ & $3.21^{* *}$ \\
\hline R-square & \multicolumn{2}{|c|}{0.1719} & \multicolumn{2}{|c|}{0.0426} & \multicolumn{2}{|c|}{0.1211} \\
\hline Chow Test & \multicolumn{2}{|c|}{$9.08^{* * *}$} & \multicolumn{2}{|c|}{$2.09^{* * *}$} & \multicolumn{2}{|c|}{$2.14^{* * *}$} \\
\hline Hausman Test & \multicolumn{2}{|c|}{$19.69^{* * *}$} & \multicolumn{2}{|c|}{$14.26^{\star *}$} & \multicolumn{2}{|c|}{$28.34^{\star * *}$} \\
\hline
\end{tabular}

Notes: ${ }^{*}$ significant at $10 \%,{ }^{* *}$ significant at $5 \%,{ }^{* * *}$ significant at $1 \%$. 
to invest in receivables to realize their sales. Although we fail to empirically show that short cash cycles affect firms' profitability, our results are in line with Abuzayed (2012) who also demonstrate the positive relationship between working capital management and profitability.

Meanwhile, for model 2, the results of the fixed effect robustness show that working capital management does not directly affect sustainable growth. These findings are inconsistent with Fonseka et al. (2012) who show that working capital management affects sustainable growth. As empirically shown by the next model, we argue that it is likely that our insignificant results are due to the presence of other variables that mediate the effect of working capital management on sustainable growth.

However, after including firms' profitability in the specification, working capital management significantly affects sustainable growth (Model 3). Also, the results suggest that firms' profitability significantly affects their sustainable growth. Increased firms' ability to generate profits will enhance their sustainable growth. Our results are in line with previous studies that demonstrate that profitability affects firms' sustainable growth (Amouzesh et al. 2011, Fonseka et al. 2012, Manaf et al. 2018, Rahim 2017). These findings suggest that increased profitability will provide more internal funds for firms to support sustainable growth. Besides, the inclusion of the profitability variable in the specification that changes the significance of the effect of working capital management and sustainable growth (from an insignificant effect to a significant effect), we conclude that profitability is a variable that mediates the relationship between these two variables.

Besides, the results of the Sobel test, Goodman (Arorian) test, and Goodman test in Table 4 confirm that profitability mediates the relationship between working capital management and sustainable growth. Accordingly, firms can increase their sustainable growth by increasing their ability to generate profits or profitability. Increased profitability facilitate firms to generate internal funds that are important to increase their sustainable growth. In this condition, firms are likely to grow without having to rely much on external financing with higher financing costs for their investments in current and fixed assets. Thus, working capital management that is closely related to the way firms manages their business operations becomes very crucial. Firms can adopt appropriate working capital management policies. Further,

Table 4. The results of the mediating effect (secondary data, processed)

\begin{tabular}{|l|l|}
\hline \multicolumn{1}{|c|}{ Mediation Test } & Coefficient \\
\hline Sobel & $0.0111^{* * *}$ \\
\hline Goodman-1 (Aroian) & $0.0111^{* * *}$ \\
\hline Goodman-2 & $0.0111^{* * *}$ \\
\hline
\end{tabular}

Notes: ${ }^{\star}$ significant at $10 \%,{ }^{* *}$ significant at $5 \%,{ }^{* *}$ significant at $1 \%$. because our empirical findings demonstrate that longer cash cycles positively affect profitability, conservative investment policies in current assets and current assets financing can be alternative working capital policies for manufacturing firms. However, firms should not invest in cash, securities, receivables, and inventory too much because it will increase their holding cost and financing cost that harm their profitability and eventually their sustainable growth.

\section{Conclusions and future research}

This study analyzes the relationship between working capital management, firms' profitability, and sustainable growth. The results demonstrate that working capital management is significantly associated with firms' profitability. Further, although not directly affecting sustainable growth, working capital management significantly affects sustainable growth through firms' profitability. Our empirical results offer both theoretical and practical implications. Theoretically, this study contributes by extending the literature in working capital management that mainly focuses on profitability and not investigates further the effect of working capital management on sustainable growth as mediated by firms' profitability. Practically, by demonstrating that profitability is a variable that mediates the relationship between working capital management and sustainable growth, our study advises firms to focus on their working capital management to enhance their profitability and eventually their sustainable growth. Increased profitability facilitates firms to acquire more internal funds that will eventually enhance their sustainable growth. In this condition, firms could grow without having to rely much on external financing sources with higher financing costs for their investments both in current assets and fixed assets. Thus, firms have to pay considerable attention to working capital management. Further, although our findings show that longer cash cycles positively affect firms' profitability, firms should not invest excessively in cash, marketable securities, receivables, and inventories and take the holding cost and financing cost of these assets into consideration to maintain their profitability and eventually their sustainable growth.

Previous studies show inconsistent results in investigating the effect of working capital management on firms' profitability. These inconsistent results offer a research avenue on the possible non-linear relationship between these two variables. Further, there are no studies that use the Indonesian context and test the non-linear relationship between working capital management and profitability. The condition provides an ample opportunity to investigate such issue in Indonesia. Besides, different industry characteristics cause greater variability in firms' cash cycles. We then advise future studies focus on the cross-country analysis of firms in the same industries to generate a better understanding of firms' working capital management. 


\section{Disclosure statement}

Authors declare that they have no competing financial, professional, or personal interests from other parties

\section{References}

Abuzayed B (2012) Working capital management and firms' performance in emerging markets: the case of Jordan. International Journal of Managerial Finance 8 (2): 155-179. https:// doi.org/10.1108/17439131211216620

Adekola A, Samy M, Knight D (2017) Efficient working capital management as the tool for driving profitability and liquidity: a correlation analysis of Nigerian companies. International Journal Business and Globalisation 18 (2): 251-275. https:// doi.org/10.1504/IJBG.2017.081957

Afrifa GA (2015) Working capital management practices and profitability of AIM Listed SMEs. Journal of Enterprising Culture 23: 1-23. https://doi.org/10.1142/S0218495815500016

Afrifa GA, Tingbani I (2018) Working Capital management, cash flow and SME's performance. International Journal Banking, Accounting, and Finance 9: 19-43. https://doi.org/10.1504/ IJBAAF.2018.10010466

Ahmad B, Samim MM (2018) Working capital management efficiency and corporate governance in manufacturing sector of Pakistan working capital management efficiency and corporate governance in manufacturing sector of Pakistan. European Online Journal of Natural and Social Science 7 (1): 67-87.

Al-abass HS (2018) Effect of working capital management on profitability of cement sector listed companies. Finance and Management Sciences 8 (1): 137-142. https://doi.org/10.6007/ IJARAFMS/v8-i1/3927

Altaf N, Shah FA (2018) How does working capital management affect the profitability of Indian companies? Journal of Advances in Management Research 15 (3): 373-366. https:// doi.org/10.1108/JAMR-06-2017-0076

Amouzesh N, Moeinfar Z, Mousavi Z (2011) Sustainable growth rate and firm performance: evidence from Iran stock exchange. International Journal of Business and Social Science 2 (23): $249-255$.

Ashta A (2008) Sustainable growth rates: refining a measure. Briefings in Entrepreneurial Finance 214: 207-214. https:// doi.org/10.1002/jsc.827

Atta S, Javed H, Khalil MJ, Ahmad I, Nadeem M (2017) Relationship between working capital and corporate performance in the textile sector of Pakistan. International Journal of Family Business and Management 1: 1-5. https://doi. org/10.15226/2577-7815/1/1/00106

Attom BE (2016) Working capital management as a financial strategy to improve profitability and growth of micro and small scale enterprise. International Journal of Research in Commerce and Management 7 (7): 42-50.

Bagh T, Nazir MI, Khan MA, Khan MA, Sadaf R (2016) The impact of working capital management on firms financial performance: evidence from Pakistan. International Journal of Economics and Financial Issues 6 (4): 1097-1105.

Baltagi BH (2005) Econometric analysis of panel data (3rd Edit). New York: John Wiley \& Sons.
Barine MN (2012) Working capital management efficiency and corporate profitability: Evidences from quoted firms in Nigeria. Journal of Applied Finance \& Banking 2 (2): 215-237.

Baron RM, Kenny DA (1986) The moderator-mediator variable distinction in social psychological research: conceptual, strategic, and statistical considerations. Journal of Personality and Social Psychology 51 (6): 1173-1182. https://doi. org/10.1037/0022-3514.51.6.1173

Churchill NC, Mullins Lj (2001) How fast can your company afford to grow? Harvard Business Review 79 (5): 135-143.

Deloof M (2003) Does working capital management affect profitability of Belgian firms? Journal of Business Finance \& Accounting 30 (May): 573-588. https://doi.org/10.1111/14685957.00008

Fonseka M, Ramos CG, Tian G-L (2012) The most appropriate sustainable growth rate model for managers and researchers. The Journal of Applied Business Research 28 (3): 481-500. https://doi.org/10.19030/jabr.v28i3.6963

Gill A, Biger N, Mathur N, Palmer S, Street WH, Vb-k BC (2010) The relationship between working capital management and profitability: evidence from The United States. Business and Economics Journal (2010): 1-9.

Gitman LJ (2011) Principle of managerial finance (13th ed). New Jersey: Prentice Hall.

Hien Tran, Abbott M, Jin-Yap C (2017) How does working capital management affect the profitability of Vietnamese small and medium-sized enterprises? Introduction. Journal of Small Business and Enterprise Development 24: 2-11.

Higgins RC (1977) How much growth can a firm afford? Financial Management 6 (Fall): 7-16. https://doi.org/10.2307/3665251

IDN Financials (2018) Financial Data https://www.idnfinancials. com/pricing

Indonesian Stock Exchange (2018) Annual Report https://www. idx.co.id/en-us/about-idx/annual-report/

Koralun-Bereźnicka J (2014) On the relative importance of corporate working capital determinants: findings from the EU Countries. Contemporary Economics 8 (4): 415-434. https:// doi.org/10.5709/ce.1897-9254.154

Lamptey LL, Frimpong K, Morrison AB (2017) Empirical study on the influence of working capital management on performance of SMEs in a developing economytle. British Journal of Economics, Management \& Trade 217 (4): 1-10.

MacKinnon DP (2008) Introduction to statistical mediation analysis. Mahwah, NJ: Mahwah, NJ: Erlbaum.

Manaf NBA, Saad NBM, Mohamad NEAB, Ali IBM, Rahim NB (2018) Determinants of Sustainability Growth Rate (SGR) by using Zakon's model to encounter with Shariah compliance requirements for Shariah securities compliance firms in Malaysia. International Journal of Industrial Management 4 (June): 61-69.

Mannori E, Mohammad J (2012) The determinant of working capital management of manufacturing companies: case of Singapore firms. Research Journal of Finance and Accounting 3 (11): 15-23.

Mehta MSP (2017) Working capital management and firms' profitability: evidence from emerging Asian countries. South Asian Journal of Business Studies 6 (1): 80-97. https://doi. org/10.1108/SAJBS-09-2015-0060 
Misbah S, Anjum MJ, Aqdas MI, Khan N, Abdur M, Khan R (2015) The Relationship between working capital management and profitability: evidence from listed companies in Kuala Lumpur Stock Exchange (KSE) Malaysia. International Journal of Information Processing and Management 6 (1): 104-113.

Momčilović M, Begović SV, Tomašević S, Ercegovac D (2015) Sustainable Growth Rate: Evidence from agricultural and food enterprises. Management 20 (76): 63-75. https://doi. org/10.7595/management.fon.2015.0017

Mukherjee T, Sen SS (2018) Sustainable growth: a study on some selected banks in India. International Journal of Money, Banking and Finance 6 (1): 52-59.

Oseifuah EK, Gyekye A (2016) Cash conversion cycle theory and corporate profitability: Evidence from non-financial firms listed on the Johannesburg Stock Exchange. Journal of Accounting and Management 6 (9): 37-51.

Padachi K, Howorth C, Narasimhan MS (2012) Working capital financial preferences: the case of Mauritian manufacturing Small and Medium-Sized Enterprises (SMEs). Asian Academy of Management Journal of Accounting and Finance 8 (1): 125-157.

Palombini NNV, Nakamura W (2012) Key factors in working capital management in the Brazilian market. Revista de Administração de Empresas 52 (1): 55-69. https://doi. org/10.1590/S0034-75902012000100005

Panda AK, Nanda S (2018) Working capital financing and corporate profitability of Indian manufacturing firms. Management Decision 56 (2): 441-457. https://doi.org/10.1108/ MD-07-2017-0698
Pass C, Pike R (1996) Management of working capital: a neglected. Innovation \& Entrepreneurial Research 25 (1): 18-24. https:// doi.org/10.1108/eb001430

Rădăşanu AC (2015) Cash-flow sustainable growth rate models. Journal of Public Administration, Finance and Law (7): 62-70.

Raheman A, Afza T, Qayyum A, Bodla MA (2010) Working capital management and corporate performance of manufacturing sector in Pakistan. International Research Journal of Finance and Economics 47: 151-163.

Raheman A, Nasr M (2007) Working capital management and profitability-case of Pakistani firms. International Review of Business Research Papers 3 (1): 279-300.

Rahim N (2017) Sustainable growth rate and firm performance: a case study in Malaysia. International Journal of Management, Innovation \& Entrepreneurial Research 3 (2): 48-60. https:// doi.org/10.18510/ijmier.2017.321

Shapiro AC, Balbirer SD (2000) Modern corporate finance: a multidisciplinary approach to value creation. New Jersey: Prentice Hall.

Smith KV (1973) State of the art of working capital management. Financial Management 2 (3): 50-55. https://doi. org/10.2307/3664987

Vural G (2012) Affects of working capital management on firm's performance: evidence from Turkey. International Journal of Economics and Financial Issues 2 (4): 488-495.

Wasiuzzaman S (2015) Working capital and profitability in manufacturing firms in Malaysia: an empirical study. Global Business Review 16 (4): 545-556. https://doi. org/10.1177/0972150915581098 